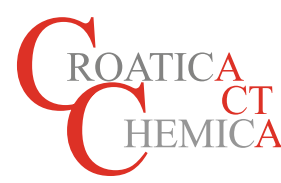

\title{
Učenici se sjećaju Siniše Maričića (1926.-2017.): Uspravan do kraja
}

\author{
Stanimir Vuk-Pavlović, Bojan Benko, Vesna Svetličić
}

Uvod: Siniša Maričić umro je 31. listopada 2017. Tim su povodom troje njegovih učenika elektronskim putem razmijenili uspomene na dr. Maričića. Te uspomene ovdje žele podijeliti s čitateljima časopisa Croatica Chemica Acta.

SV-P: Kao učenici iz njegova znanstvenog razdoblja u biofizici tvrdimo, možda sebično, da je upravo tada dr. Maričić ostavio najvažniji trag. Izvjesno je da je njegov najvažniji doprinos našoj znanosti upravo onaj koji je trajao najkraće: njegov pionirski doprinos razvoju biofizike, biofizičkog obrazovanja i kvantitativnog pristupa biološkim problemima. Bio nam je učiteljem u svoj punini tih pojmova, a na nas je utjecao i svojom osobnošću. Zato nam nije cilj ovdje nabrajati niti raščlanjivati mnogobojne doprinose $d r$. Maričića kemijskoj tehnologiji nakon Il. svjetskog rata, potom njegovo predvodništvo u biofizici i, na koncu, u znanosti o znanosti $^{[1-4]}$, već podijelimo radije osobne uspomene na nj.

BB: Na početku gimnazijskog školovanja bio sam sklon prirodnim predmetima. Vjerovao sam da ću nakon srednje škole studirati fiziku. Međutim, izvrsna nastavnica kemije je uložila mnogo truda da pouči svakog tko je želio mnogo više kemije od propisanoga pa sam se upisao na studij kemije, ali sam i dalje ostao sklon fizici. U jesen g. 1972. izrađivao sam diplomski rad na Institutu Ruđer Bošković. Moj me tadašnji mentor prof. Nenad Trinajstić upitao bih li se želio baviti biofizikom. Tada doista nisam znao što je biofizika. Prof. Trinajstić me je uputio dr. Maričiću koji je vodio laboratorij za strukturnu biofiziku u zgradi susjednog Instituta za fiziku. Nisam baš znao kako se pripremiti za razgovor. $S$ malo treme potražio sam $d r$. Maričića u njegovu laboratoriju. Dojmljiva brada, plave oči i smireni ton - kao da je bio svjestan moje treme. No, već nakon nekoliko minuta treme je nestalo. Razgovarali smo najviše o mojim interesima i očekivanjima, a tek onda o onome što mi može ponuditi. O svemu smo se brzo dogovorili. Danas znam da su posljedice tog razgovora nadmašile sva moja očekivanja.

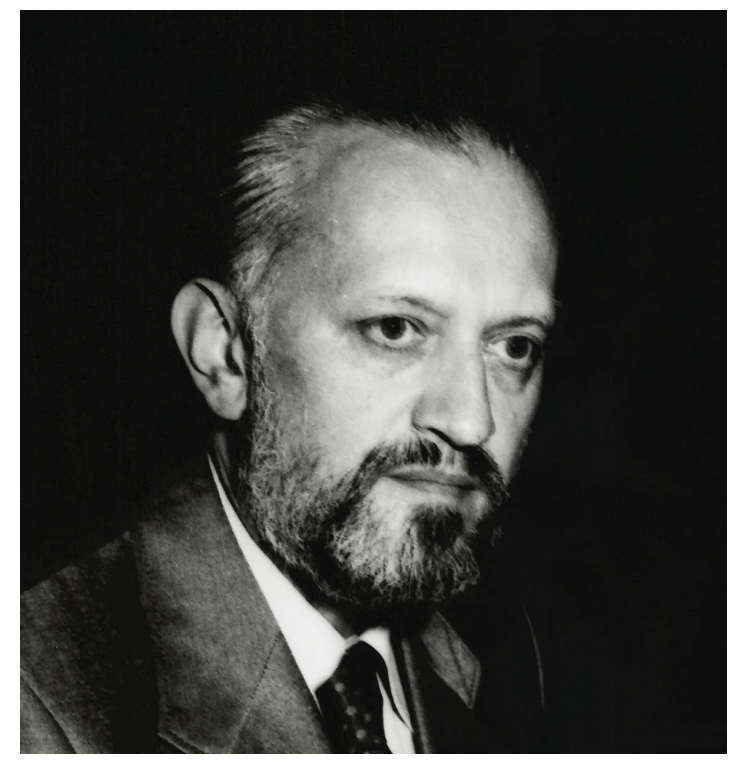

Siniša Maričić (1926.-2017.)

SV-P: Dr. Maričić bio je i moj poslijediplomski i doktorski mentor. Radio sam s njime od jeseni g. 1972. do prosinca g. 1976., ukupno kojih četiri godine i četvrt. Prvi put sam susreo dr. Maričića negdje u ranu jesen 1972. godine, nekoliko mjeseci po obrani diplomskoga rada. Poznavao sam prof. Kristu Kostial koju sam zamolio za savjet kako i komu dalje na poslijediplomski studij: "Maričić radi kvantitativnu znanost. Razgovaraj s njime!" Kako sam upravo završio studij na kojem sam izrijekom čuo da "biologija nije kvantitativna znanost", nisam dvojio što mi je činiti.

Dr. Maričić me je primio u prostorijama tadašnjeg Instituta za biologiju kojemu je bio na čelu. Dr. Kostial me je

(c) BY $\mathbf{B Y}$ This work is licensed under a Creative Commons Attribution 4.0 International License. 
pripremila podatkom da se Institutu "klima" i da je njegova opstojnost upitna. Tijekom razgovora shvatio sam da me je završeni studij slabo pripremio za biofizička istraživanja kakvima se dr. Maričić bavio, ali mi je odmah bilo jasno da moram prihvatiti izazov. Na kraju razgovora dr. Maričić mi reče kako je moguće da će "Institut potonuti, a i on zajedno s njim". Odgovorio sam nešto poput "Bolje je s dobrim tonuti, nego $s$ lošim plivati". Naš je odnos toga časa bio uspostavljen; dr. Maričić je katkad u društvu znao tu našu izmjenu navesti.

BB: U Hrvatskoj je biofizika bila sasvim mlada, a ja sam dobio priliku raditi u tom području na najboljem mjestu. Dr. Maričić je okupio mlade biologe, fizičare i kemičare, opremio je prvi biofizički laboratorij u Hrvatskoj i osigurao financiranje za nekoliko godina istraživanja građe i funkcije hemoproteina. Organizirao je međusveučilišni poslijediplomski studij strukturne biofizike s nastavom koju se izvodili najbolji sveučilišni profesori i istaknuti znanstvenici iz Zagreba i Ljubljane. To je sedamdesetih godina prošlog stoljeća bila jedina nastava biofizike u Jugoslaviji. U sklopu tog studija održavale su se ljetne škole na koje su dolazili studenti, ali i stručnjaci iz drugih područja iz cijele bivše države i inozemstva. Razina nastave bila je vrlo visoka, a dala je studentima i priliku da upoznaju i neke od najboljih svjetskih znanstvenika. Cilj je studija bio povezati fiziku, kemiju i biologiju u rješavanju bioloških problema, te studentima pružiti komplementarna znanja koja nisu mogli steći tijekom osnovnog studija. Kasnije je ta škola prerasla u međunarodnu u organizaciji dr. Grete Pifat, dugogodišnje suradnice dr. Maričića.

VS: Nikad nisam izravno surađivala s dr. Maričićem, ali sam sudjelovala u ljetnim školama u okviru postdiplomskog studija biofizike, prvi put g. 1973. na llidži. Bila sam duboko uronjena u biofiziku koju je on uveo i etablirao kod nas. Od svog akademskog početka vidjela sam znanost sličnim očima kao i dr. Maričić. Njegov postdiplomski studij biofizike mi je omogućio artikuliranje onoga čime se želim baviti, prometom tvari kroz biomembrane; to me je odvelo sve do biofizike mora. Entuzijazam, ozbiljnost, etičnost, ljubav prema prirodi, sve se to nekako prirodno prelijevalo i zapljuskivalo nas mlade na početku znanstvene karijere.

BB: Nastava na poslijediplomskom studiju strukturne biofizike bila je dobra, korisna i zanimljiva, ali središnju ulogu imala su znanstvena istraživanja. Dr. Maričić je svojim suradnicima dopuštao široku slobodu istraživanja i poticao je njihove inicijative. Pritom im je nastojao omogućiti što bolje uvjete. Laboratorij koji je osnovao raspolagao je $s$ prvim pulsnim NMR spektrometrom u Hrvatskoj prilagođenim za relaksacijska mjerenja, ORD/CD spektrometrom, UV/VIS spektrometrom i osnovnom opremom za pročišćavanje biomakromolekula. Potencijal laboratorija dodatno je uvećan suradnjom s Institutom Ruđer Bošković u Zagrebu, Institutom Jožef Stefan u Ljubljani, Fakultetom za zemjodelski nauki i hrana u Skoplju, s Central Institute of Molecular Biology/Max Delbruck Center for Molecular Medicine u Berlinu, Institutom za kristalografiju Ruske akademije znanosti i dr. U takvom smo okruženju mi mladi studenti postali produktivni istraživači u tada vrlo kompetitivnom području strukture i funkcije hemoproteina.

SV-P: Laboratorij se nalazio u zgradi Instituta za fiziku na Bijeničkoj cesti. Kako su studenti i suradnici laboratorija radili više-manje neprekidno, s vremena na vrijeme vidjelo se da dr. Maričića nema u uredu u prizemlju. To je bilo doba njegova članstva i rada u Centralnom komitetu Saveza komunista Hrvatske što mu je oduzimalo podosta vremena. Videći da nam katkada nedostaje njegovo prisustvo i vodstvo, znao se požaliti na izgubljeno vrijeme. "Pa, dr. Maričić, zašto to radite ako Vas to toliko zamara i odvlači toliko vremena i snage?" "Znate, Vuk, nitko zapravo ne radi nešto što ne želi!" Nakon nekog vremena povukao se iz politike. Koliko se sjećam, govorio je da je to učinio iz načelnih razloga.

Vrijeme provedeno u laboratoriju bilo je za nas suradnike itekako produktivno. Razmjerno velik broj publikacija tih godina pružio je priliku da me dr. Maričić poduči o načelima koja su trajno ostala sa mnom. Jedno od načela jest da pri navođenju reda autora treba biti pravedan, ali i velikodušan; "Znate, Vuk, na kraju se uvijek zna tko je dobar, a tko nije." Produktivnost je dovela i do poziva da pišemo revijske prikaze svog područja: "Držite se primarne produkcije, a neka revijske prikaze pišu drugi!"

BB: Krajem g. 1974. Institut za biologiju Sveučilišta u Zagrebu u čijem je sklopu radio Laboratorij za strukturnu biofiziku, zapao je u teškoće. Laboratorij je zajedno s osobljem organizacijski prešao u Imunološki zavod. Znanstvena su se istraživanja nastavila pa i proširila na područje citokroma P-450, i trajala su još tri godine.

SV-P: Ukidanje Instituta za biologiju i prelazak u Imunološki zavod dr. Maričić je teško primio. Novo je okruženje postavilo nove i neočekivane izazove za sve u grupi. Te izazove nisu olakšale ni poteškoće s održavanjem i nužnim unapređivanjem tada razmjerno jedinstvene instrumentacije. No, trud i ugled dr. Maričića u Zagrebu i Institutu Jožef Štefan u Ljubljani ipak su omogućili da se instrumenti održavaju i nadograđuju, da se radi uglavnom bez prekida, i da se rukopisi za tisak i radovi za napredovanje na vrijeme završavaju.

Po povratku s prvog dijela svog poslijedoktorskog studija samim krajem g. 1977. na stolu u svom stanu 
zatekao sam dugačko rukom pisano pismo kojim mi dr. Maričić javlja da odlazi iz Imunološkog zavoda. Nažalost, tog pisma više nemam, ali se sjećam da je pažljivo pokazivalo brigu za moj daljnji profesionalni put. Pisao je i o načelnim razlozima zašto je morao otići iz Zavoda. Taj je odlazak okončao naš zajednički rad i, velikim dijelom, naše kontakte da bismo se kasnije opet nalazili, uglavnom o njegovom rođendanu, sve do prije nekoliko godina kada mu je zdravlje počelo predstavljati teret.

VS: Hrvatsko biofizičko društvo vodila sam od 2002. do 2010. godine. Dr. Maričić bio je tihi član društva, ali je unosio entuzijazam, snagu i ozbiljnost. Bio je važna podrška dignitetu Društva, a time i statusu biofizike u znanstvenoj zajednici. Pratio je pravac kretanja, glavne pomake, a katkada i odmake od biofizike. Tako smo vodili razgovore o uspostavljanju biofizike mora kao nove znanstvene discipline, ili pak o doktorskom studiju biofizike osnovanom na Prirodoslovno-matematičkom fakultetu u Splitu. Na sjednicama/sastancima Društva uvijek je sjedio u zadnjem redu, ali je prvi plaćao članarinu.

Na godišnjoj skupštini Hrvatskoga biofizičkog društva 27. siječnja 2017. dr. Maričić je izabran za prvog počasnog člana. U obrazloženju prijedloga predsjednik N. Pavin je predstavio ulogu dr. Maričića kao začetnika biofizike u Hrvatskoj i bivšoj državi, kao i osnivača i prvog predsjednika Jugoslavenskog biofizičkog društva kojemu je Hrvatsko biofizičko društvo de facto sljednik. Ja sam dodatno prikazala ulogu dr. Maričića u početku biofizike u Hrvatskoj i šire.

BB: Vrijeme provedeno s dr. Maričićem kao voditeljem, znanstvenikom i čovjekom bitno je utjecalo na moj profesionalni život. Bilo je to za mene sjajnih pet godina.

Vs: Na kraju, dijelili smo i godine u mirovini. To je u stvari bio nastavak, proširenje i nadogradnja dotadašnjem profesionalnom vrtu druženja. Podržavao je angažiranost u znanosti, kao i konkretne društvene akcije koje su odmaknute od politike.

SV-P: U pogledima na život $s$ dr. Maričićem moglo se i ne slagati, ali ga se moralo poštovati zbog iskrenosti i čvrstoće stavova. Bio je predvodnik znanstvenog razvoja. Bio je pošten. Kada je morao, odlazio je da sačuva vlastita načela. Otišao je uspravan do kraja.

BB: Bojan Benko, bojan.benko@gmail.com

VS: Vesna Svetličić, svetlicic@irb.hr

SV-P: Stanimir Vuk-Pavlović, vuk@mayo.edu

\section{IZVORI}

[1] Biografski podaci i sveukupna bibliografija dr. sc. Siniše Maričića dostupni je na borut.com/sinisa_maricic/

[2] Doprinosi dr. sc. Siniše Maričića razvoju biofizike te uvođenju i primjeni metode nuklearne magnetske rezonancije u Hrvatskoj opisani su na mrežnoj stranici Hrvatskog biofizičkog društva (www.biofizika.hr) onama/iz-povijesti-drustva) i Prirodoslovno-matematičkog fakulteta Sveučilišta u Zagrebu (www.pmf. unizg.hr/phy/NMR/nmr_tehnika/nmr_u_hrvatskoj).

[3] Videozapis svjedočenja dr. sc. Siniše Maričića o svom životu dostupan je na www.osobnasjecanja.hr/videoarhiva/sinisa-maricic.

[4] Napomena Urednika: Među brojnim znanstvenostručnim aktivnostima ${ }^{[1-2]}$ bio je (nakon profesora Bože Težaka) i glavni urednik časopisa Croatica Chemica Acta (1980.-1985.). Na nesebičnom obavljanju dužnosti glavnog urednika časopisa Croatica Chemica Acta, Hrvatsko kemijsko društvo duguje mu trajnu zahvalnost. 